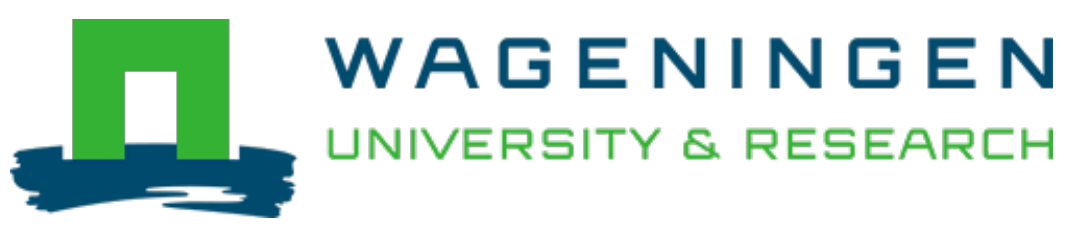

\title{
Structure of the genetic diversity in Black poplar (Populus nigra L.) populations across European river systems: consequences for conservation and restoration
}

\author{
Forest Ecology and Management \\ Smulders, M.J.M.; Cottrell, J.E.; Lefevre, F.; Schoot, J.; Arens, P.F.P. et al \\ https://doi.org/10.1016/j.foreco.2007.10.063
}

This article is made publicly available in the institutional repository of Wageningen University and Research, under the terms of article $25 \mathrm{fa}$ of the Dutch Copyright Act, also known as the Amendment Taverne. This has been done with explicit consent by the author.

Article 25 fa states that the author of a short scientific work funded either wholly or partially by Dutch public funds is entitled to make that work publicly available for no consideration following a reasonable period of time after the work was first published, provided that clear reference is made to the source of the first publication of the work.

This publication is distributed under The Association of Universities in the Netherlands (VSNU) 'Article $25 \mathrm{fa}$ implementation' project. In this project research outputs of researchers employed by Dutch Universities that comply with the legal requirements of Article $25 \mathrm{fa}$ of the Dutch Copyright Act are distributed online and free of cost or other barriers in institutional repositories. Research outputs are distributed six months after their first online publication in the original published version and with proper attribution to the source of the original publication.

You are permitted to download and use the publication for personal purposes. All rights remain with the author(s) and / or copyright owner(s) of this work. Any use of the publication or parts of it other than authorised under article $25 \mathrm{fa}$ of the Dutch Copyright act is prohibited. Wageningen University \& Research and the author(s) of this publication shall not be held responsible or liable for any damages resulting from your (re)use of this publication.

For questions regarding the public availability of this article please contact openscience.library@,wur.nl 


\title{
Structure of the genetic diversity in black poplar (Populus nigra L.) populations across European river systems: Consequences for conservation and restoration
}

\author{
M.J.M. Smulders ${ }^{\text {a,* }}$, J.E. Cottrell ${ }^{\text {b }}$, F. Lefèvre ${ }^{c}$, J. van der Schoot ${ }^{\text {a }}$, P. Arens ${ }^{a}$, \\ B. Vosman ${ }^{\text {a }}$, H.E. Tabbener ${ }^{\text {b }}$, F. Grassi ${ }^{\mathrm{d}}$, T. Fossati ${ }^{\mathrm{d}, 1}$, S. Castiglione ${ }^{\mathrm{d}, 2}$, \\ V. Krystufek ${ }^{\mathrm{e}, \mathrm{m}}$, S. Fluch ${ }^{\mathrm{e}}$, K. Burg ${ }^{\mathrm{e}}$, B. Vornam $^{\mathrm{f}}$, A. Pohl ${ }^{\mathrm{g}}$, K. Gebhardt ${ }^{\mathrm{g}, 3}$, \\ N. Alba ${ }^{\mathrm{h}}$, D. Agúndez ${ }^{\mathrm{h}}$, C. Maestro ${ }^{\mathrm{i}}$, E. Notivol ${ }^{\mathrm{i}}$, R. Volosyanchuk ${ }^{\mathrm{j}}$, M. Pospíš́kovák $^{\mathrm{k}}$, \\ S. Bordács ${ }^{1}$, J. Bovenschen ${ }^{\mathrm{m}}$, B.C. van Dam ${ }^{\mathrm{m}}$, H.P. Koelewijn ${ }^{\mathrm{m}}$, D. Halfmaerten ${ }^{\mathrm{n}}$, \\ B. Ivens ${ }^{n}$, J. van Slycken ${ }^{n}$, A. Vanden Broeck ${ }^{n}$, V. Storme ${ }^{o}$, W. Boerjan ${ }^{\circ}$ \\ ${ }^{a}$ Plant Research International, Wageningen UR, NL-6700 AA Wageningen, The Netherlands \\ ${ }^{\mathrm{b}}$ Forest Research, Northern Research Station, Roslin, Midlothian, Scotland EH25 9SY, UK \\ ${ }^{\mathrm{c}}$ INRA, Unité de Recherches Forestières Méditerranéennes, 84000 Avignon, France \\ ${ }^{\mathrm{d}}$ University of Milan, Department of Biology, 20133 Milan, Italy \\ ${ }^{\mathrm{e}}$ Austrian Research Center, Department of Biotechnology, 2444 Seibersdorf, Austria \\ ${ }^{\mathrm{f}}$ University of Göttingen, Institute of Forest Genetics and Forest Tree Breeding, 37077 Göttingen, Germany \\ ${ }^{\mathrm{g}}$ Hessian Forest Centre for Management Planning, Research and Ecology, 34346 Hannover Muenden, Germany \\ ${ }^{\mathrm{h}}$ CIFOR-INIA, Department of Breeding and Biotechnology, 28080 Madrid, Spain \\ ${ }^{\mathrm{i}}$ Forest Resources Unit, CITA, Government of Aragon, 50080 Zaragoza, Spain \\ ${ }^{\mathrm{j}}$ Ukrainian Research Institute of Forestry and Forest Melioration (URIFFM), Department of Tree Breeding, Pushkinska 86, Kharkiv 61024, Ukraine \\ ${ }^{\mathrm{k}}$ VÚKOZ, v.v.i. 252, 43 Průhonice, Czech Republic \\ ${ }^{1}$ OMMI, Budapest, Hungary \\ ${ }^{\mathrm{m}}$ Alterra, Wageningen UR, NL-6700 AA Wageningen, The Netherlands \\ ${ }^{\mathrm{n}}$ Research Institute for Nature and Forest, 9500 Geraardsbergen, Belgium \\ ${ }^{\circ}$ VIB, Ghent University, 9052 Gent, Belgium
}

Received 24 July 2007; received in revised form 19 October 2007; accepted 29 October 2007

\begin{abstract}
Black poplar (Populus nigra L.) is a keystone species for riparian ecosystems in Europe. We analysed the structure of genetic diversity of 17 populations from 11 river valleys that are part of seven catchment systems (Danube, Ebro, Elbe, Po, Rhine, Rhone, and Usk) in Europe, in relation to geography and river management. In total, 1069 trees were genotyped using AFLP and microsatellite markers.

The trees had an observed heterozygosity of 0.74 (range $0.59-0.82$ across microsatellite loci). The majority (72.6-90.8\%, depending on the marker system) of the genetic variation was present within populations. Most pairs of populations along a river were relatively similar (pairwise $F_{\text {st }}$ 0.042-0.135 based on AFLP, $0.002-0.037$ based on microsatellites). Overall population differentiation among rivers was considerable $\left(F_{\text {st }}\right.$ among populations was 0.268 based on AFLP, and 0.081 based on microsatellites). An analysis using the program Structure indicated that all populations recruited plants from several clusters. Geographically close populations tended to draw from the same Structure clusters, including populations from adjacent catchments. The Danube and Inn populations in Austria were genetically more similar to the Vltava population (Elbe catchment) in Czech Republic than the geographically more distant populations along the Tisa and Prut rivers of the Danube catchment in Ukraine. This indicates
\end{abstract}

\footnotetext{
Tel.: +31 317 476982/480840; fax: +31317418094.

E-mail address: Rene.smulders@wur.nl (M.J.M. Smulders).

${ }^{1}$ Current address: University of Milano Bicocca, Department of Biotechnologies and Biosciences, 20126 Milano, Italy.

${ }^{2}$ Current address: University of Salerno, Department of Chemistry, 84084 Fisciano (SA), Italy.

${ }^{3}$ Current address: Nordwestdeutsche Forstliche Versuchsanstalt, Hann. Münden, Germany.
}

* Corresponding author at: Plant Research International, Wageningen UR, Biodiversity and Breeding, P.O. Box 16, NL-6700 AA Wageningen, The Netherlands. 
that gene flow and dispersal takes place across fairly large distances and between river catchments. Consistent with this result, a principal coordinate analysis of genetic distances among individual trees based on AFLP bands showed large overlap of populations, although the French and Spanish samples formed distinct clusters, and the samples from the Ticino (Italy) were at an intermediate position.

The extent of clonal duplication was highest along regulated rivers, with e.g., $41 \%$ clonal duplication along the Rhine in The Netherlands (up to 32 trees for one genet). The Usk contained a man-made population (two genotypes along the entire river, one genet present as 70 trees out of 72 trees sampled). No clonal duplication was found along dynamic rivers, such as the Ebro (Spain), the Drome (France), and the Tisa and Prut (Ukraine).

It is concluded that the restoration of the natural habitat and the re-creation of the natural dynamics of the floodplain, in combination with sufficiently sized and spaced natural populations as seed sources, are the most important measures for sufficient natural regeneration and conservation of this species in the future.

(C) 2007 Elsevier B.V. All rights reserved.

Keywords: AFLP; Microsatellite marker; Clonal propagation; River dynamics; Riparian ecosystem; Population genetics

\section{Introduction}

It has been estimated that up to $99 \%$ of the riparian forests in Europe have disappeared (Lefèvre et al., 1998; Hughes and Rood, 2003) as a result of human activities (control of river dynamics, wood cutting and cattle grazing). Currently, there is an increasing interest to restore the riparian habitats of European rivers (Hughes et al., 2005) and to use woody vegetation communities on the floodplain for flood control. Black poplar (Populus nigra L.) plays a central role in the initial phase of the development of riparian forests. Poplar seeds are dispersed by wind and water, and seedlings can establish themselves along riverbanks on sites which have experienced natural winter floods (Van Splunder et al., 1995; Mahoney and Rood, 1998; Rood et al., 2005). Poplars also propagate naturally from broken twigs and branches which are transported along rivers and root on riverbanks (Braatne et al., 1996). A combination of generative and vegetative propagation is common in Populus and Salix (e.g., Cheliak and Dancik, 1982; Barsoum et al., 2004; Barsoum, 2003; Douhovnikoff et al., 2005; Namroud et al., 2005; Reisch et al., 2007).

The amount of successful seedling establishment depends on local dynamics (Legionnet et al., 1997) and on the local seed rain. Projects which aim to restore riverbanks to their former natural state rely on existing $P$. nigra trees to supply seed for recolonisation. It is therefore important to know how much genetic variation in black poplar remains along different rivers (Cottrell et al., 1997; Arens et al., 1998; Winfield et al., 1998). There must be sufficient genetic diversity to provide the population with the capacity to adapt to changing environmental conditions in order to ensure its long-term survival (Booy et al., 2000). Therefore the aim of this study was to determine the population genetic structure of this species, and to investigate to what extent genetic diversity has been affected by human activities.

We have applied two molecular marker techniques, AFLP and microsatellite markers, to assess the genetic diversity of $P$. nigra populations along seven catchment systems across Europe. Some of the rivers that were sampled have remained highly dynamic (Drome, Ticino and Ebro), while others (Rhine, Danube and Vltava) have been channelized and their flow is being regulated more or less tightly. The populations sampled along these rivers include natural populations as well as populations, such as along the Usk, which have been directly or indirectly influenced by humans. Specifically, we determined geographic differentiation of the populations within and between river systems, and whether there are genetic differences between dynamic rivers and regulated rivers, also in the extent of vegetative propagation. From this, we derive advice and suggestions on how to conserve and restore genetic diversity in black poplar.

\section{Materials and methods}

\subsection{Sampling}

Initially, we designed a hierarchical sampling strategy: two cohorts per population (juvenile vs. adult) and two or more populations per river catchment (Table 1; Country and population codes follow ISO 3166-1 (alpha-2)). The location of the populations is indicated in Fig. 1. The Drome, Ebro, and Ticino can be considered as unregulated rivers, while the Usk, Rhine, Vltava and Danube (except for its tributaries; the Tysa and Prut) are managed in terms of water level, and have been partly channelized. Wherever possible, two populations were sampled within $100 \mathrm{~km}$. To avoid introgressions from exotic poplar species we selected natural populations with only trees that were morphologically $P$. nigra. No ornamental $P$. nigra var. italica were present in the study areas. The trees looked morphologically as black poplar, so it is unlikely that hybrid cultivars have been included. Offspring of $P$. nigra trees sired by $P$. $x$ canadensis cannot be ruled out completely, but this seems unlikely as mostly large natural populations have been selected, the PCO (see below) does not indicate outlier trees, and an additional study on introgressions in The Netherlands (Smulders et al., in preparation) in which this population was included together with hybrid cultivars, did not identify any of its trees as putatively of hybrid origin.

In each population, 30 mature trees were sampled, as well as 30 juvenile trees (defined as non-reproductive, identified by stem diameter of $1-5 \mathrm{~cm}$, which means that they are at most 510 years old). Trees were sampled randomly across the population, with juveniles usually at the margin of the adult stand. Due to the lack of recent recruitment, only mature cohorts were collected from four of the 17 populations (see 
Table 1

The populations sampled

\begin{tabular}{|c|c|c|c|c|c|c|}
\hline $\begin{array}{l}\text { Population } \\
\text { code }\end{array}$ & River (catchment) & Location of population $^{a}$ & Cohort $(s)^{b}$ & $\begin{array}{l}\text { Description of river } \\
\text { management }^{c}\end{array}$ & $\begin{array}{l}\text { Microsatellites } \\
\text { analysed in the } \\
\text { laboratory in }\end{array}$ & $\begin{array}{l}\text { AFLP data } \\
\text { from the BE } \\
\text { and NL laboratory }\end{array}$ \\
\hline AT1 & Danube & $\begin{array}{l}\text { Vienna island, Eferding } \\
\text { (Austria), } 48^{\circ} 18^{\prime} \mathrm{N}, \\
14^{\circ} 05^{\prime} \mathrm{E}\end{array}$ & Mature & Controlled & AT & + \\
\hline AT2 & Inn (Danube) & $\begin{array}{l}\text { Near Lobau (Austria), } \\
48^{\circ} 09^{\prime} \mathrm{N}, 16^{\circ} 33^{\prime} \mathrm{E}\end{array}$ & Mature & Controlled & AT & + \\
\hline $\mathrm{CZ}$ & $\begin{array}{l}\text { Labe (Elbe) and its } \\
\text { side-river Vltava } \\
\text { near their junction } \\
\text { at Melnik }\end{array}$ & $\begin{array}{l}\text { Between Kralupy n. } \\
\text { Vltava and Melnik, north } \\
\text { of Prague, (Czech Republic), } \\
50^{\circ} 15^{\prime} 31.16^{\prime \prime} \mathrm{N}, 14^{\circ} 28^{\prime} 42.06^{\prime \prime} \mathrm{E}\end{array}$ & Juvenile/mature & Controlled & $\mathrm{CZ}$ & - \\
\hline DE1 & Rhine & $\begin{array}{l}\text { Near Kühkopf (Germany), } \\
49^{\circ} 49^{\prime} \mathrm{N}, 08^{\circ} 30^{\prime} \mathrm{E}\end{array}$ & Juvenile/mature & Dynamic/controlled & $\mathrm{DE}$ & + \\
\hline DE2 & Rhine & $\begin{array}{l}\text { Near Polder Altenheim } \\
\text { (Germany) }\end{array}$ & Juvenile/mature & Dynamic/controlled & $\mathrm{DE}$ & + \\
\hline ES1 & Ebro & $\begin{array}{l}\text { Near Novillas (Spain), } \\
41^{\circ} 55^{\prime} 32^{\prime \prime} \mathrm{N}, 1^{\circ} 21^{\prime} 46^{\prime \prime} \mathrm{W}\end{array}$ & Juvenile/mature & Dynamic & AT & + \\
\hline ES2 & Ebro & $\begin{array}{l}\text { Near Alfranca (Spain), } \\
41^{\circ} 35^{\prime} 21^{\prime \prime} \mathrm{N}, 0^{\circ} 45^{\prime} 34^{\prime \prime} \mathrm{W}\end{array}$ & Juvenile/mature & Dynamic & AT & + \\
\hline FR1 & Drôme (Rhone) & $\begin{array}{l}\text { Along the Drôme (France) }{ }^{\mathrm{d}} \text {, } \\
44^{\prime} 41^{\prime \prime} \mathrm{N}, 5^{\prime} 24^{\prime \prime} \mathrm{E}\end{array}$ & Juvenile/mature & Dynamic & FR & + \\
\hline FR2 & Drôme (Rhone) & $\begin{array}{l}\text { Along the Drôme (France) } \\
44^{\prime} 45^{\prime \prime} \mathrm{N}, 4^{\prime} 55^{\prime \prime} \mathrm{E}\end{array}$ & Juvenile/mature & Dynamic & FR & + \\
\hline IT1 & Ticino $(\mathrm{Po})$ & Near La Zelata (Italy) & Juvenile/mature & Dynamic & IT & + \\
\hline IT2 & Ticino $(\mathrm{Po})$ & Inside Bosco Siro Negri (Italy) & Juvenile/mature & Dynamic & IT & + \\
\hline NL & Waal (Rhine) & $\begin{array}{l}\text { River dune near Gendt, east of } \\
\text { Nijmegen (The Netherlands) }\end{array}$ & Mature & Controlled & NL & + \\
\hline GB & Usk & $\begin{array}{l}\text { Along whole river }(100 \mathrm{~km}) \text {, } \\
\text { Wales, } \mathrm{UK}^{\mathrm{f}}\end{array}$ & Mature & Dynamic & UK & + \\
\hline UA-Ch & $\begin{array}{l}\text { Tysa (or Tisza) } \\
\text { (Danube) }\end{array}$ & $\begin{array}{l}\text { Chorna Hora (Ukraine), } \\
48^{\circ} 07^{\prime} 30^{\prime \prime} \mathrm{N}, 23^{\circ} 04^{\prime} 55^{\prime \prime} \mathrm{E}\end{array}$ & Juvenile/mature & Dynamic & NL & - \\
\hline UA-Kh & $\begin{array}{l}\text { Tysa (or Tisza) } \\
\text { (Danube) }\end{array}$ & $\begin{array}{l}\text { Khust (Ukraine), } \\
48^{\circ} 10^{\prime} 55^{\prime \prime} \mathrm{N}, 23^{\circ} 14^{\prime} 20^{\prime \prime} \mathrm{E}\end{array}$ & Juvenile/mature & Dynamic & NL & - \\
\hline UA-Ko & Prut (Danube) & $\begin{array}{l}\text { Kolomyia (Ukraine), } \\
48^{\circ} 31^{\prime} 00^{\prime \prime} \mathrm{N}, 25^{\circ} 01^{\prime} 30^{\prime \prime} \mathrm{E}\end{array}$ & Juvenile/mature & Dynamic & NL & - \\
\hline UA-Za & Prut (Danube) & $\begin{array}{l}\text { Zabolotiv (Ukraine), } \\
49^{\circ} 28^{\prime} 40^{\prime \prime} \mathrm{N}, 25^{\circ} 17^{\prime} 00^{\prime \prime} \mathrm{E}\end{array}$ & Juvenile/mature & Dynamic & NL & - \\
\hline
\end{tabular}

${ }^{\mathrm{a}}$ Nearest town or landmark.

b juvenile trees were 5-10 years old.

c controlled, if flow of water has been confined to a narrow river bed to make a river navigable; dynamic, if floodplain is large and allowed to be inundated freely.

d Population 1 of Imbert and Lefèvre (2003).

e Population 6 of Imbert and Lefèvre (2003).

${ }^{\mathrm{f}}$ Collection of trees scattered along the river, since no clear population' could be defined.

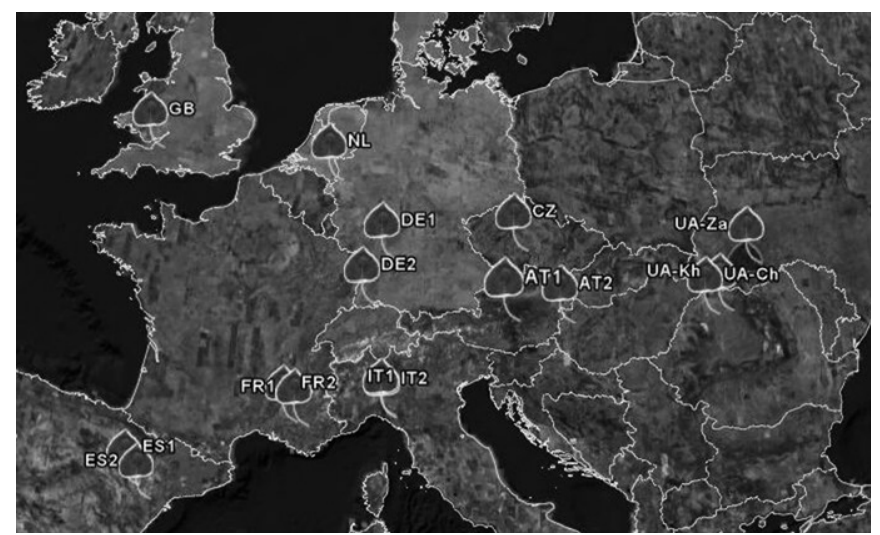

Fig. 1. Map of central Europe indicating the location of the populations sampled for this study.
Table 1). Some of the populations consisted of patchily distributed trees, which were sampled along a long stretch of the river (populations GB and CZ), or populations were small and were therefore sampled completely (populations NL and AT2). All samples were collected in 1999, except the Czech samples along the Vltava (collected in 2000) and those from the Ukrainian populations along the Tisa and Prut rivers (collected in 2002).

For DNA extraction, one young, expanding leaf was collected from each tree, frozen immediately in liquid nitrogen and stored at $-20{ }^{\circ} \mathrm{C}$. Prior to DNA extraction, the samples were lyophilised and ground with five to seven glass beads in a Retch shaking mill. DNA extractions were performed with the DNeasy kit (Qiagen, Venlo, The Netherlands). Table 2 contains the final number of trees sampled. 
Table 2

Data on the number of duplicate genotypes identified, and the size of duplicate groups

\begin{tabular}{|c|c|c|c|c|c|}
\hline Population & $\begin{array}{l}\text { Total number of } \\
\text { individuals sampled }\end{array}$ & $\begin{array}{l}\text { Number of unique } \\
\text { genotypes }\end{array}$ & $\begin{array}{l}\text { Number of trees } \\
\text { with duplicated } \\
\text { genotypes }\end{array}$ & $\begin{array}{l}\text { Clonal or genotype } \\
\text { diversity, } R[(G-1) / \\
(N-1)]^{\mathrm{a}}\end{array}$ & $\begin{array}{l}\text { Number of } \\
\text { individuals in the } \\
\text { largest clone }\end{array}$ \\
\hline AT1-AT2 & 111 & 97 & 14 & 0.87 & 10 \\
\hline $\mathrm{CZ}$ & 59 & 59 & 0 & 1.00 & 1 \\
\hline DE1-DE2 & 138 & 131 & 7 & 0.95 & 8 \\
\hline ES1-ES2 & 119 & 119 & 0 & 1.00 & 1 \\
\hline FR1-FR2 & 130 & 130 & 0 & 1.00 & 1 \\
\hline IT1-IT2 & 132 & 124 & 8 & 0.94 & 5 \\
\hline NL & 120 & 71 & 49 & 0.59 & 32 \\
\hline GB & 72 & 2 & 70 & 0.01 & 70 \\
\hline UA-h, -Kh & 105 & 105 & 0 & 1.00 & 1 \\
\hline $\mathrm{UA}-\mathrm{Ko},-\mathrm{Za}$ & 83 & 83 & 0 & 1.00 & 1 \\
\hline Total & 1069 & 915 & 148 & 0.86 & \\
\hline
\end{tabular}

The same duplicate genotypes were identified by AFLP and by microsatellites. Population codes as in Table 1 .

a After Dorken and Eckert (2001).

\subsection{AFLP protocol}

The AFLP method was carried out on samples from 12 populations (i.e., all except those from the Vltava, Tisa and Prut rivers), essentially as described by Vos et al. (1995) with some modifications (Arens et al., 1998; Cervera et al., 2001). Total genomic DNA (300 ng) was prepared in a one-step restrictionligation reaction with $5 \mathrm{U}$ EcoRI and $5 \mathrm{U}$ MseI (Life Technologies, Invitrogen, Breda, The Netherlands) in $40 \mu \mathrm{l}$ $10 \mathrm{mM}$ Tris- $\mathrm{HCl}$ buffer, $10 \mathrm{mM}$ magnesium acetate, $50 \mathrm{mM}$ potassium acetate and $\mathrm{pH} 7.5$ for $1 \mathrm{~h}$ at $37{ }^{\circ} \mathrm{C}$. Subsequently, $10 \mu \mathrm{l}$ of a ligation mixture containing 5 pmol EcoRI adapter, 50 pmol MseI adapter (Isogen) and 2 U T4 DNA ligase (Life Technologies) in the same buffer as before but with $0.4 \mathrm{mM}$ ATP added, was incubated further for $3 \mathrm{~h}$ at $37^{\circ} \mathrm{C}$. The resulting primary template was diluted to $200 \mu \mathrm{l}$ with $10 \mathrm{mM}$ Tris-HCl, $0.1 \mathrm{mM}$ EDTA $\mathrm{pH} 8.0$ and stored at $-20{ }^{\circ} \mathrm{C}$ prior to use. The first PCR step (preamplification) was performed on primary template using a primer pair based on the sequences of the EcoRI and MseI adapter with one additional selective nucleotide at the $3^{\prime}$-end (E01-M01, 5'-GACTGCGTACCAATTCA-3' and 5'-GATGAGTCCTGAGTAAA-3'). Amplification reactions $(20 \mu \mathrm{l})$ contained $5 \mu \mathrm{l}$ of primary template, $30 \mathrm{ng}$ of each primer, $0.4 \mathrm{U}$ Goldstar polymerase (Eurogentec, Seraing, Belgium), $0.2 \mathrm{mM}$ of all four dNTPs, $10 \mathrm{mM}$ Tris$\mathrm{HCl} \mathrm{pH} 8.3,50 \mathrm{mM} \mathrm{KCl}, 1.5 \mathrm{mM} \mathrm{MgCl}_{2}$ and $0.001 \%$ gelatine. Preamplification products were diluted 20-fold with $10 \mathrm{mM}$ Tris-HCl, 0.1 mM EDTA pH 8.0.

This preamplification mixture was exchanged between two partners (Wageningen and Gent). In this way, both laboratories could perform the amplification, separation, and detection for the complete set of samples, which ensured reproducibility. The selective PCR amplification was performed at 1 cycle $94{ }^{\circ} \mathrm{C}$ for $30 \mathrm{~s}, 65^{\circ} \mathrm{C}$ for $30 \mathrm{~s}$ and $72{ }^{\circ} \mathrm{C}$ for $1 \mathrm{~min}$, using a touchdown protocol $\left(65^{\circ} \mathrm{C}\right.$ annealing temperature was reduced by $0.7^{\circ} \mathrm{C}$ for 12 cycles, then kept at $56{ }^{\circ} \mathrm{C}$ for the remaining 23 cycles). In Wageningen, primer pair E32-M36 (5'-GACTGCGTACCAATTCAAC- $3^{\prime}$ and $5^{\prime}$-GATGAGTCCTGAGTAAACC- $3^{\prime}$ ) was amplified with $5 \mathrm{ng}$ of ${ }^{33} \mathrm{P}$-labelled EcoRI primer as in
Arens et al. (1998) and Smulders et al. (2000). The gels were scanned and scored using QuantarPro (Keygene, Wageningen, The Netherlands). In Gent, primer pair E44-M40 (5'GACTGCGTACCAATTCATC-3' and 5'-GATGAGTCCTGAGTAAAGC-3') was analysed on an ABI (Applied Biosystems) sequencer following Cervera et al. (2001). E32M36 produced 52 polymorphic bands and E44-M40 produced 53 polymorphic bands.

\subsection{Microsatellite analysis}

Seven microsatellite (or SSR, simple sequence repeat) loci (PMGC14, WPMS09, WPMS12, WPMS14, WPMS16, WPMS18, and WPMS20) were used. One (PMGC14) was selected from the IPGC (International Populus Genome Consortium) SSR Resource (http://www.ornl.gov/sci/ipgc/ ssr_resource.htm) and the six others from Van der Schoot et al. (2000) and Smulders et al. (2001). These markers are located on different chromosomes, except WPMS09 and WPMS12 which are on the same linkage group, but $60 \mathrm{~cm}$ apart (Cervera et al., 2001; Gaudet et al., 2008). Markers were amplified in $20 \mu \mathrm{l}$ containing $75 \mathrm{mM}$ Tris- $\mathrm{HCl} \mathrm{pH}$ 9.0, $1.5 \mathrm{mM}$ $\mathrm{MgCl}_{2}, 20 \mathrm{mM}\left(\mathrm{NH}_{4}\right)_{2} \mathrm{SO}_{4}, 0.01 \%$ (w/v) Tween $20,100 \mu \mathrm{M}$ of each dNTP, $200 \mathrm{nM}$ of each primer, $16 \mathrm{ng}$ template DNA and 0.1 U Goldstar DNA polymerase (Eurogentec) as described by Smulders et al. (2001). Amplification products were separated on denaturating polyacrylamide gels and visualized using a silver staining procedure (Promega Silver Sequence DNA Sequencing System) or with fluorescence detection on ABI automatic sequencers, depending on the laboratory.

Microsatellite analysis was performed in seven laboratories (see Table 1). Reference samples were distributed to guide the identification of alleles across laboratories, and identification and scoring of the alleles was standardised to a one-letter code (allele A, B, C, etc.). The reproducibility of the scoring process was checked with a ring test (cf. Bredemeijer et al., 2002; Röder et al., 2002) with one $P$. nigra cv. Italica sample and 22 blind samples from the EUFORGEN Core Collection (as described in Storme et al., 2004). Comparison of the results of different 
laboratories indicated that these microsatellites were reliably genotyped across laboratories and detection methods.

\subsection{Data analysis}

For each AFLP primer combination polymorphic bands were recorded and given a serial number. Presence (1) or absence (0) of each polymorphic band was scored for all genotypes. Similarity for each pair of samples was calculated using Dice similarity. All individual samples were clustered by means of UPGMA (Unweighted Pair Group Method with Arithmetic mean; results not shown) to detect identical trees (indicating vegetative reproduction), and analysed by PCO (principle coordinate analysis) using NTSYSpc 2.11s. AFLP-SURV 1.0 (Vekemans et al., 2002) was used to calculate gene diversity statistics and estimate significance of $F_{\text {st }}$ estimates from the AFLP data.

Microsatellite data were analysed using Fstat 2.9.3 (Goudet, $1995)$ to calculate diversity measures. Based on the microsatellite data an estimate of the number of genetic clusters represented in the samples was made using the program STRUCTURE 2.0 (Falush et al., 2003), run without prior population information. This program uses a Markov chain Monte Carlo (MCMC) method that clusters individuals to minimize Hardy-Weinberg disequilibrium and linkage disequilibrium between loci. Runs were performed with a burn-in length of 10,000 and a MCMC of 100,000 using the admixture model. The range of possible number of clusters $(K)$ tested was from 1 to 18 . Based on the initial results of these runs, series of five runs each were performed for $K$ s between 6 and 13 .

The partitioning of variation at different levels was calculated for AFLP and microsatellite data by an AMOVA (analysis of molecular variance) in Arlequin 3.1 (Excoffier et al., 2005) using 1000 permutations.

\section{Results}

\subsection{Clonal propagation}

In general, trees were sampled across the populations to obtain an upper estimate of genetic diversity of the whole population. We were aware that this strategy would result in overlooking small clonal groups (as found by Barsoum et al. (2004) along the Garonne). Nevertheless, larger clonal groups were detected in the dataset. Both AFLP and SSR analysis identified the same duplicated genotypes. Overall, 148 (14\%) of the 1069 trees included in the study were duplicates (genotype diversity 0.86; Table 2). Most duplicate genotypes were found in populations along rivers with reduced natural dynamics and high levels of human activity: the Rhine (41\% vegetative propagation in The Netherlands, up to 32 trees for one genet) and the Usk (97\% duplicates, up to 70 trees formed a single genet, and only two different genotypes were discovered along the whole river). Much lower levels (13\% or less clonal duplication) were found in the Italian, Austrian and German populations, and these were nearly always the result of just two clonal replicates of a single tree. No duplicate clones occurred in our sample from populations along the Spanish, French, Czech and Ukrainian rivers. Except for the river Usk, groups of identical ramets were confined to a single local population, which is consistent with development from root suckers. As we did not systematically sample successive populations along one river, we cannot estimate the contribution of rooting of branches and twigs carried down stream by the river. The pattern along the river Usk is clearly the result of planting by man. For the population genetic analyses with AFLP and microsatellites, the groups of duplicate genotypes were reduced to one individual tree each, and the two genotypes planted along the Usk were excluded from the analyses.

\subsection{Genetic diversity assessed with AFLP}

Diversity within and among populations was assessed using two AFLP primer pairs, which produced 105 polymorphic bands. $\mathrm{Hj}$ (analogous to Nei's gene diversity or $\mathrm{He}$ ) varied from 0.139 to 0.183 (Table 3$)$. The highest values (0.176 and 0.183 ) were found in the Italian populations.

Juvenile and adult cohorts within populations were genetically quite similar $\left(F_{\text {st }} 0.005-0.030\right.$, except in the FR2 population, where it was 0.13 ). Nevertheless, the differentiation was statistically significantly (Table 4) in all but one.

Table 3

Genetic diversity as estimated by AFLP (two primer pairs)

\begin{tabular}{|c|c|c|c|c|c|c|c|}
\hline Population & $\begin{array}{l}\text { Number of } \\
\text { plants analysed }\end{array}$ & $\begin{array}{l}\text { Number } \\
\text { of loci }\end{array}$ & $\begin{array}{l}\text { Number of loci } \\
\text { with frequency } \\
\text { between } 0.05 \text { and } \\
0.95(\%)\end{array}$ & $\begin{array}{l}\text { Expected } \\
\text { heterozygosity } \\
\mathrm{Hj}( \pm \text { S.E. })\end{array}$ & Variance of $\mathrm{Hj}$ & $\begin{array}{l}\% \text { of variance } \\
\text { of } \mathrm{Hj} \text { due to } \\
\text { sampling of } \\
\text { individuals }\end{array}$ & $\begin{array}{l}\% \text { of variance } \\
\text { of } \mathrm{Hj} \text { due to } \\
\text { sampling of loci }\end{array}$ \\
\hline AT1 & 49 & 104 & $38(36.5 \%)$ & $0.140 \pm 0.016$ & 0.000242 & 10.4 & 89.6 \\
\hline AT2 & 43 & 104 & $43(41.3 \%)$ & $0.146 \pm 0.016$ & 0.000256 & 10.2 & 89.8 \\
\hline DE1 & 52 & 104 & $62(59.6 \%)$ & $0.157 \pm 0.015$ & 0.000212 & 13.4 & 86.6 \\
\hline DE2 & 55 & 104 & $40(38.5 \%)$ & $0.146 \pm 0.016$ & 0.000245 & 10.9 & 89.1 \\
\hline IT1 & 59 & 104 & $50(48.1 \%)$ & $0.183 \pm 0.017$ & 0.000295 & 7.2 & 92.8 \\
\hline IT2 & 49 & 103 & $66(64.1 \%)$ & $0.176 \pm 0.016$ & 0.000243 & 10.9 & 89.1 \\
\hline FR1 & 61 & 104 & $37(35.6 \%)$ & $0.148 \pm 0.017$ & 0.000302 & 13 & 87 \\
\hline FR2 & 54 & 99 & $40(40.4 \%)$ & $0.168 \pm 0.019$ & 0.000364 & 5.6 & 94.4 \\
\hline ES1 & 57 & 103 & $38(36.9 \%)$ & $0.152 \pm 0.018$ & 0.000314 & 6 & 94 \\
\hline ES2 & 57 & 103 & $39(37.9 \%)$ & $0.142 \pm 0.016$ & 0.000271 & 7.6 & 92.4 \\
\hline NL & 67 & 104 & $41(39.4 \%)$ & $0.146 \pm 0.016$ & 0.000252 & 7.7 & 92.3 \\
\hline
\end{tabular}

Population codes as in Table 1. 
Table 4

Population differentiation

\begin{tabular}{|c|c|c|c|c|c|c|}
\hline \multirow{3}{*}{ Population } & \multicolumn{6}{|l|}{$F_{\text {st }}$ values } \\
\hline & \multicolumn{3}{|l|}{ AFLP data } & \multicolumn{3}{|l|}{ Microsatellite data } \\
\hline & $\begin{array}{l}\text { Between cohorts } \\
\text { within populations }\end{array}$ & $\begin{array}{l}\text { Between } \\
\text { populations }\end{array}$ & Overall & $\begin{array}{l}\text { Between cohorts } \\
\text { within populations }\end{array}$ & $\begin{array}{l}\text { Between } \\
\text { populations }\end{array}$ & Overall \\
\hline AT1 & & $0.1346^{* *}$ & & & $0.0366 *$ & \\
\hline \multicolumn{7}{|l|}{ AT2 } \\
\hline DE1-juvenile & $0.0296 * *$ & $0.0589 * *$ & & & $0.0154 * *$ & \\
\hline DE1-adult & & & & $0.0207 \mathrm{NS}$ & & \\
\hline DE2-juvenile & $0.0048 *$ & & & & & \\
\hline DE2-adult & & & & $0.0115 \mathrm{NS}$ & & \\
\hline IT1 & & $0.1222 * *$ & & & $0.0109 \mathrm{NS}$ & \\
\hline \multicolumn{7}{|l|}{ IT2 } \\
\hline FR1-juvenile & $0.0927 * *$ & & & $0.0244 \mathrm{NS}$ & $0.0193 *$ & \\
\hline \multicolumn{7}{|l|}{ FR1-adult } \\
\hline FR2-juvenile & $0.1321 * *$ & & & $0.0151 \mathrm{NS}$ & & \\
\hline FR2-adult & & $0.129 * *$ & & & & \\
\hline ES1-juvenile & $0.0221 * *$ & & & $-0.0023 \mathrm{NS}$ & $0.0002 \mathrm{NS}$ & \\
\hline \multicolumn{7}{|l|}{ ES1-adult } \\
\hline ES2-juvenile & $0.0127 \mathrm{NS}$ & & & $0.0231 \mathrm{NS}$ & & \\
\hline ES2-adult & & $0.0422 * *$ & & & & \\
\hline \multicolumn{7}{|l|}{ NL } \\
\hline UA-Ch-juvenile & & & & $0.0271 \mathrm{NS}$ & $0.0188 * * *$ & \\
\hline \multicolumn{7}{|l|}{ UA-Ch-adult } \\
\hline UA-Kh-juvenile & & & & $0.0059 \mathrm{NS}$ & & \\
\hline \multicolumn{7}{|l|}{ UA-Kh-adult } \\
\hline UA-Ko-juvenile & & & & $0.0031 \mathrm{NS}$ & $0.0191 * * *$ & \\
\hline \multicolumn{7}{|l|}{ UA-Ko-adult } \\
\hline UA-Za-juvenile & & & & $0.0041 \mathrm{NS}$ & & \\
\hline \multicolumn{7}{|l|}{ UA-Za-adult } \\
\hline CZ-juvenile & & & & $0.0279 *$ & & \\
\hline \multicolumn{7}{|l|}{ CZ-adult } \\
\hline All & & & $0.268 * *$ & & & $0.081 * *$ \\
\hline
\end{tabular}

The table contains pairwise and overall $F_{\text {st }}$ estimates. Population codes as in Table $1 . * P<0.05 ; * * P<0.01 ; * * * P<0.001$; NS: not significant.

Most pairs of populations within a country or along a river were also significantly differentiated, with $F_{\text {st }}$ values ranging between 0.04 and 0.13 . Overall population differentiation was considerable ( $F_{\text {st }}$ among the 12 populations was 0.268 ), with pairwise $F_{\text {st }}$ values varying from 0.042 to 0.527 (mean pairwise value 0.246; Table $\mathrm{S} 1$ ).
A hierarchical AMOVA showed that $72.9 \%$ of the genetic variation was present within populations, $11.5 \%$ between the two populations along a river, and $15.6 \%$ between catchments (Table 5). Since most of the variation was present within populations, we assessed the structure of differentiation using a PCO analysis of all individual trees (Fig. 2). In this plot, the

Table 5

Hierarchical partitioning of genetic variation using AMOVA

\begin{tabular}{|c|c|c|c|c|c|c|c|c|c|c|c|c|}
\hline \multirow[b]{2}{*}{ Source of variation } & \multicolumn{4}{|c|}{ AFLP data of 11 populations $^{\mathrm{a}}$} & \multicolumn{4}{|c|}{ Microsatellite data of 11 populations ${ }^{b}$} & \multicolumn{4}{|c|}{ Microsatellites data of 16 populations ${ }^{\mathrm{b}, \mathrm{c}}$} \\
\hline & d.f. & $\begin{array}{l}\text { Sum of } \\
\text { squares }\end{array}$ & $\begin{array}{l}\text { Variance } \\
\text { components }\end{array}$ & $\begin{array}{l}\text { Percentage } \\
\text { of variation }\end{array}$ & d.f. & $\begin{array}{l}\text { Sum of } \\
\text { squares }\end{array}$ & $\begin{array}{l}\text { Variance } \\
\text { components }\end{array}$ & $\begin{array}{l}\text { Percentage } \\
\text { of variation }\end{array}$ & d.f. & $\begin{array}{l}\text { Sum of } \\
\text { squares }\end{array}$ & $\begin{array}{l}\text { Variance } \\
\text { components }\end{array}$ & $\begin{array}{l}\text { Percentage } \\
\text { of variation }\end{array}$ \\
\hline Among catchments & 5 & 355.366 & 0.45578 & 15.64 & 5 & 100.817 & 0.07886 & 7.28 & 8 & 168.35 & 0.09119 & 7.95 \\
\hline $\begin{array}{l}\text { Among populations } \\
\text { within catchments }\end{array}$ & 5 & 106.724 & 0.33362 & 11.45 & 5 & 16.696 & 0.0206 & 1.9 & 7 & 21.244 & 0.01867 & 1.63 \\
\hline Within populations & 637 & 1353.835 & 2.12533 & 72.92 & 271 & 1250.492 & 0.98386 & 90.82 & 760 & 1824.15 & 1.03645 & 90.42 \\
\hline Total & 647 & 1815.924 & 2.91473 & & 281 & 1368.005 & 1.08332 & & 775 & 2013.745 & 1.1463 & \\
\hline \multicolumn{13}{|l|}{ Fixation indices } \\
\hline$F_{\text {st (population-overall) }}$ & & & & 0.2708 & & & & 0.0918 & & & & 0.0958 \\
\hline$F_{\text {sc (population-catchment) }}$ & & & & 0.1357 & & & & 0.0205 & & & & 0.0177 \\
\hline$F_{\text {ct (catchment-overall) }}$ & & & & 0.1564 & & & & 0.0728 & & & & 0.0796 \\
\hline
\end{tabular}

${ }^{\text {a }}$ Based on AFLP data of 41 loci with less than $5 \%$ missing values.

${ }^{\mathrm{b}}$ Only three microsatellite markers (PMGC14, WPMS16, and WPMS20) had less than 5\% missing values.

${ }^{\mathrm{c}}$ Including the Vltava, Tisa and Prut populations. 


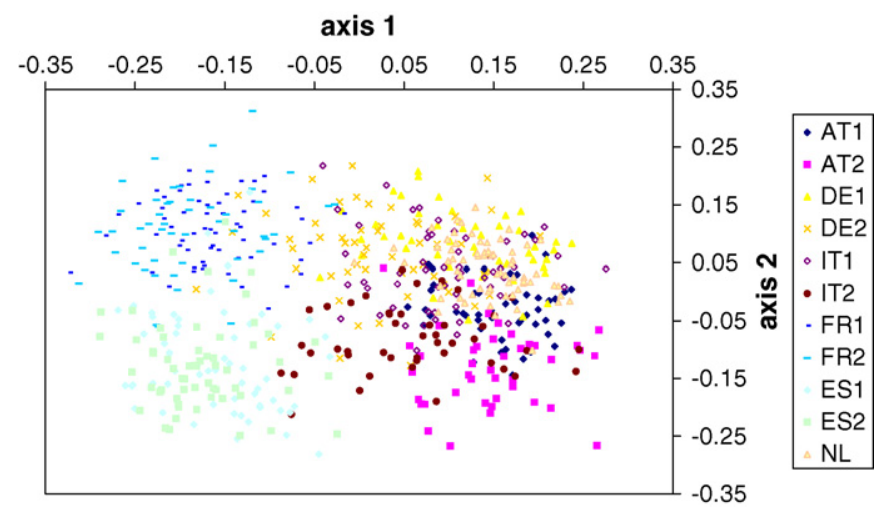

Fig. 2. Principle coordinate analysis (PCO) plot of individuals samples, based on AFLP data. Abbreviations for the populations as in Table 1.

French and Spanish populations appear as two distinct clusters. In addition, the Austrian and Italian samples also tend to group together, but they clearly overlap with each other and also with the German and Dutch samples.

\subsection{Genetic diversity assessed with microsatellites}

In the microsatellite analysis we also included populations along the Vltava (and Labe) river in Czech Republic (part of the Elbe catchment), and along the Tisa and Prut rivers in Ukraine, which are tributaries of the Danube and which extend the studied area further to the Southeast of Europe. Heterozygosity estimates (Table 6) were much higher than with AFLP, consistent with the large number of alleles at microsatellite loci (Nybom, 2004). Both in the microsatellite dataset of 11 populations and in the set extended with the five additional populations, the absolute values of overall and pairwise $F_{\text {st }}$ values were much lower compared to the AFLP data (Table 4). As much as $90.8 \%$ of the total variation was present within population, $1.9 \%$ between the populations in one catchment, and only $7.3 \%$ between catchments (Table 5).

Nevertheless, the structure of population differentiation derived from the microsatellite data was largely the same as that obtained from the AFLP data. Juvenile and adult cohorts had similar levels of observed and expected heterozygosity and were not significantly differentiated. After Bonferroni correction, only the comparison between cohorts along the Vltava (Czech Republic) was statistically significantly at $p<0.05$ (Table 4).
All pairs of populations along a river were significantly differentiated (except the two Italian populations along the Ticino). Overall $F_{\text {st }}$ among the 10 rivers was 0.081 (Table 4), with $F_{\text {st }}$ values among pairs of populations varying between 0.002 and 0.204 (Table S2). The mean pairwise value was 0.092. Levels of differentiation between populations close to each other along the same river were lower, varying between 0.002 (the two populations along the Ebro) and 0.037.

Gene diversity (He) varied from 0.477 to 0.907 at individual loci across populations, with an average across loci and populations of 0.756 . The lowest values were found for the Dutch population along the Rhine and, surprisingly, for the Spanish populations along the Ebro (0.704 and 0.712), while the highest value was for the Austrian population, AT2 (0.827) (Table 7). Allelic richness, which may respond faster than heterozygosity, did not vary much among populations: in samples of three individuals, summed over the seven loci, the total number of alleles varied from 23.6 in the Dutch and 23.8 in the Spanish populations to 26.4 in Austria and 26.7 along the Prut in Ukraine (not shown).

\subsection{Structure analysis of populations}

The structure of genetic differentiation among populations based on microsatellite data was assessed using the program Structure 2.0. $\operatorname{Ln}(K)$ for values of $K$ between 6 and $13(K=6$, Ln $=-20,223 ; K=7, \quad$ Ln $=-20,064 ; K=8, \quad$ Ln $=-20,325$; $K=9, \operatorname{Ln}=-19,936.18 ; \quad K=10, \quad$ Ln $=-20,434.1 ; \quad K=11$, Ln $=-20,710 ; K=12, \mathrm{Ln}=-21,265 ; K=13, \mathrm{Ln}=-21,810$; average result of five runs) indicated a lowest value at $K=9$, which is in the order of magnitude of the number of catchments in the study. In a typical analysis at $K=9$, the proportion of plants recruited for the two populations sampled close together along the same river were nearly always very similar (consistent with the very low values of the pairwise $F_{\text {st }}$ analysis; Fig. 3). The only exception was that AT2 along the Inn in Austria was at least as similar to the Czech population along the Vltava, north of Prague, than to AT1 along the Danube. The Ukrainian populations formed two pairs, which is consistent with the fact that the sampled populations are located, although geographically not far apart, along two rivers that are separated by the Carpathian mountains and that follow completely separate trajectories before joining the Danube: the Tysa (Tisza) flowing west into Hungary, the Prut flowing southeast along the Romanian border.

Table 6

Characteristics of the microsatellite markers used

\begin{tabular}{|c|c|c|c|c|c|c|c|c|}
\hline Locus & Number of alleles & Allelic richness & Ho & Hs & $\mathrm{Ht}$ & $F_{\text {it }}$ & $F_{\text {st }}$ & $F_{\text {is }}$ \\
\hline PMGC14 & 12 & 3.949 & 0.738 & 0.738 & 0.821 & 0.059 & 0.079 & -0.022 \\
\hline WPMS09 & 25 & 4.55 & 0.822 & 0.827 & 0.887 & 0.109 & 0.06 & 0.052 \\
\hline WPMS12 & 15 & 3.655 & 0.756 & 0.718 & 0.778 & 0.053 & 0.059 & -0.007 \\
\hline WPMS14 & 25 & 4.738 & 0.84 & 0.841 & 0.897 & 0.09 & 0.064 & 0.028 \\
\hline WPMS16 & 10 & 3.744 & 0.588 & 0.651 & 0.757 & 0.189 & 0.125 & 0.073 \\
\hline WPMS18 & 17 & 4.173 & 0.731 & 0.742 & 0.831 & 0.154 & 0.111 & 0.049 \\
\hline WPMS20 & 6 & 3.708 & 0.707 & 0.725 & 0.785 & 0.086 & 0.069 & 0.019 \\
\hline Overall & & & 0.74 & 0.749 & 0.822 & 0.106 & 0.081 & 0.027 \\
\hline
\end{tabular}

$99 \%$ confidence interval (bootstrapping over loci): $F_{\text {it }}=0.067-0.151 ; F_{\text {st }}=0.062-0.106 ; F_{\text {is }}=-0.003$ to 0.055 . 
Table 7

Gene diversity as estimated by microsatellites

\begin{tabular}{|c|c|c|c|c|c|c|c|c|c|c|c|c|c|c|c|c|}
\hline \multirow[t]{2}{*}{ Marker } & \multicolumn{16}{|c|}{ Population } \\
\hline & AT1 & AT2 & DE1 & DE2 & IT1 & IT2 & FR1 & FR2 & ES1 & ES2 & NL & UA-Ch & UA-Kh & UA-Ko & UA-Za & $\mathrm{CZ}$ \\
\hline PMGC14 & 0.805 & 0.798 & 0.665 & 0.74 & 0.776 & 0.656 & 0.743 & 0.746 & 0.688 & 0.732 & 0.678 & 0.853 & 0.799 & 0.826 & 0.82 & 0.79 \\
\hline WPMS09 & 0.841 & 0.888 & 0.869 & 0.85 & 0.846 & 0.842 & 0.79 & 0.867 & 0.793 & 0.825 & 0.822 & 0.653 & 0.744 & 0.819 & 0.875 & 0.865 \\
\hline WPMS12 & 0.727 & - & 0.752 & 0.75 & 0.728 & 0.865 & 0.701 & 0.794 & 0.771 & 0.825 & 0.749 & 0.693 & 0.618 & 0.676 & 0.591 & 0.725 \\
\hline WPMS14 & 0.822 & 0.871 & 0.799 & 0.775 & 0.834 & 0.846 & 0.862 & 0.852 & 0.907 & 0.89 & 0.805 & 0.864 & 0.857 & 0.85 & 0.787 & 0.804 \\
\hline WPMS16 & 0.779 & 0.809 & 0.756 & 0.602 & 0.623 & 0.675 & 0.671 & 0.608 & 0.556 & 0.508 & 0.542 & 0.821 & 0.846 & 0.808 & 0.752 & 0.788 \\
\hline WPMS18 & 0.662 & - & 0.71 & 0.747 & 0.781 & 0.766 & 0.722 & 0.831 & 0.707 & 0.728 & 0.715 & 0.825 & 0.714 & 0.797 & 0.828 & 0.668 \\
\hline WPMS20 & 0.78 & 0.767 & 0.801 & 0.798 & 0.752 & 0.752 & 0.716 & 0.732 & 0.509 & 0.477 & 0.772 & 0.834 & 0.815 & 0.799 & 0.8 & 0.819 \\
\hline Average & 0.774 & 0.827 & 0.765 & 0.752 & 0.763 & 0.772 & 0.744 & 0.776 & 0.704 & 0.712 & 0.726 & 0.792 & 0.770 & 0.796 & 0.779 & 0.780 \\
\hline
\end{tabular}

Population codes as in Table 1.

Contrary to what might have been expected, these couples of populations did not recruit distinct and separate Structureinferred clusters (Fig. 3). Rather, although each population tended to draw a major proportion of its trees from one cluster, all populations recruited trees from at least three, but more commonly four or five Structure clusters. Specifically, one can see that the populations from one catchment are only similar to the extent that they recruit gradually changing proportions from the same series of clusters (compare NL, DE2 and DE1 along the Rhine, and compare the Austrian and Ukrainian population within the Danube catchment). This indicates a substantial amount of gene flow.

\section{Discussion}

\subsection{Clonal propagation and river dynamics}

Previous studies of $P$. nigra populations in Britain, Ireland and the Netherlands have detected a high proportion of vegetatively propagated trees (Cottrell et al., 1997; Arens et al., 1998; Winfield et al., 1998; Barsoum et al., 2004; Keary et al., 2005). Poplar clones can occur in three ways: (i) anywhere, by human activities through striking of cuttings; (ii) along the length of a river, by breaking off of branches and twigs in floods, which may be carried long distances down stream; and

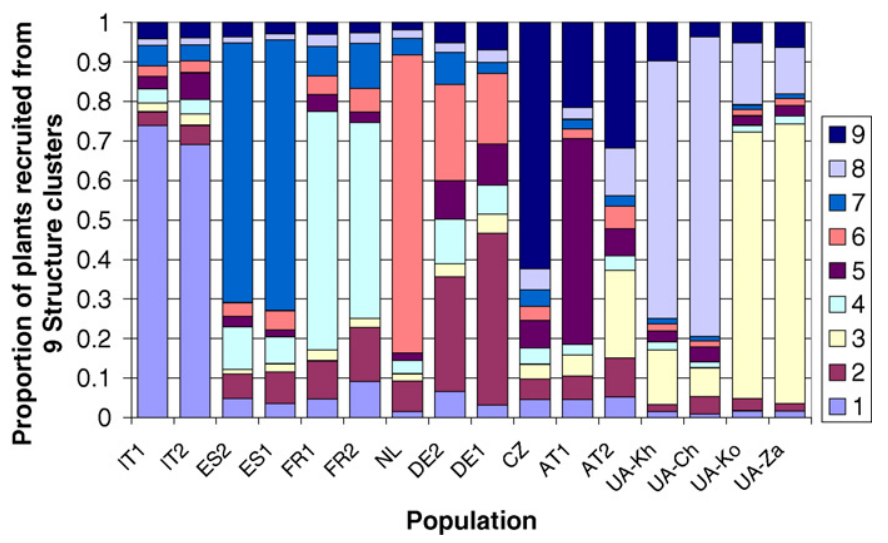

Fig. 3. Recruitment of the inferred Structure clusters from the populations studied, based on microsatellite data. For each tree in a population the Structure cluster with the highest probability was taken, from a run at $K=9$. (iii) within a population, by root suckers, which produce duplicated nearest-neighbour clones close to each other, or by 'flood training', when tree trunks are toppled and buried and ramets emerge as new shoots along a linear sequence. We did not systematically sample trees near to each other, so we have obtained no information on the occurrence of nearestneighbour clones as found by Legionnet et al. (1997) along the Loire and by Barsoum et al. (2004) along the Garonne. However, we did detect the existence of large clonal groups. The population along the Rhine in The Netherlands had $41 \%$ clonal propagation, up to 32 trees for one genet ('clone'). As all the ramets occurred in close proximity to one another they may be the result of root suckering (mechanism (iii)). Along the river Usk only two different genotypes were found, and the largest clone occurred as 70 single trees along the whole length of the river sampled. British populations appear to have experienced a high degree of human mediated interference (Cottrell et al., 1997; Winfield et al., 1998; Storme et al., 2004), and therefore these trees have most probably been planted by man (mechanism i). Much lower levels (13\% or less clonal propagation) were found along the Rhine in Germany and along the Danube in Austria. Only a few duplicates occurred along the Ticino (their origin was already discussed in Fossati et al., 2003), while no duplicate clones were identified along the unmanaged Ebro and Drome rivers, and along the Ukrainian tributaries of the Danube. Therefore, with the exception of a single clonal group of five trees along the Ticino, large duplicate groups were only identified in places with reduced river dynamics.

Hughes and Rood (2003) termed flows or flood events which promote widespread regeneration across a floodplain as 'Regeneration Flows'. Rood and Mahoney (2000) described how a major flood, after adjustment of the regulation of water flow, enabled extensive recruitment of cottonwood species. Populations along dynamic rivers have a limited age, as they will be extinguished when the river changes its path. In contrast, the Dutch population along the Rhine, with many clonal duplicates probably due to root suckering, consists of mature trees, indicating that this population must be quite old. The river management policy along a large part of the Rhine river is to control the water through the use of groynes (series of small dams perpendicular to the riverbanks). These force the water flow into the river channel, but apparently are also very efficient 
in preventing erosion of the banks, as they have completely precluded any movement of river dunes at the site of this Dutch population. Such old populations do not prevent germination of seedlings, but they will occupy the space and thus prevent establishment of new trees. As a consequence, regulated rivers support little natural regeneration of black poplar populations.

The extent of vegetative propagation and clonal duplication found here matches closely the extent of duplications found in the genebank collections of black poplar from these countries (Storme et al., 2004): in the UK, more than half of the trees in the genebank were duplicates. In the Netherlands almost half of the trees were clonal duplicates, but in the other countries these accounted for only a small percentage of the sampled trees. In the UK and the Netherlands single genotypes were duplicated many times, whereas in Austria, Spain and Italy the few duplicated clones in the genebank were present as two or three trees. Taken together, the data indicate that the genebanks succeeded in their strategy, aimed at collecting genotypes across populations in the country. This collection strategy has obviously led to duplications in collections in some countries. It will be possible to identify and exclude these with the use of the molecular markers used here.

\subsection{Juvenile and adults cohort}

The pairwise $F_{\text {st }}$ values between cohorts based on AFLP data were small but statistically significant, while based on the microsatellite data they were mostly not significant. This may be due to the much larger number of AFLP bands included, which may render also small levels of differentiation statistically significant.

We did not find differences between the juvenile and adult cohorts in genetic diversity nor in observed heterozygosity. In several tree species it has been found that heterozygosity increases from juvenile to mature trees in the same population, presumably because of selection of individuals with higher fitness. One reason for the absence of such a process between our two cohorts could be that our 'juvenile' cohorts were already 5-10 years old (this sampling strategy was chosen as the establishment of seedlings very much depends on local conditions, and therefore very young saplings did not exist in all populations). Hence, they may have already been subjected to selection. If so, observed heterozygosity in germinating seeds may be lower. A systematic comparison of seedlings with more mature cohorts has not been done in this study, but Pospúšková and Sálková (2006) found that, while mature black poplar trees had $\mathrm{He}=0.82$, similar to this study, the value for 30 seedlings was lower $(\mathrm{He}=0.74)$. Latouche-Hallé et al. (2003) found very little difference in heterozygosity in Dicorynia guianensis cohorts, of which the saplings were also a few years old.

\subsection{Diversity between rivers}

The Structure analysis of the microsatellite data distinguished as many as nine inferred clusters along the seven sampled catchments, and no single population or pair of populations along one river was found to recruit exclusively from one of these clusters. Rather, all populations drew from several (three or more) groups. The output of Structure should be interpreted carefully when more than five clusters are inferred (Structure manual). However, the low values of pairwise $F_{\text {st }}$ values based on AFLP and microsatellite results, and the overlap of individual trees from different populations in the AFLP PCO analysis, both support the conclusion that populations overlap in terms of genetic composition of their trees. This pattern is consistent with the notion that the trees in a certain region are more similar to each other than those further away, but that such regional effects concern a much wider region than a short stretch along one river. In fact, it may include different rivers, as can be seen from the similarity between the samples from the Vltava in Czech Republic and the populations along the Danube in Austria. At the level of catchments, such regional dispersal by seed (and pollen) leads to gradual changes in genetic composition of populations along the main river or along separate tributaries, so that within the Danube catchment the Tysa and Prut populations in Ukraine are more distinct from the Austrian populations along Danube and Inn than the Vltava population. Along the Rhine, the sampled populations in The Netherlands and Germany are geographically much closer, and these are indeed only gradually different from each other.

Regional dispersal is not surprising as the species is windpollinated, and produces many, very light, wind dispersed seeds. Levine and Murrell (2003) pointed out that greater seed deposition down stream than up stream along a river can drive increases in population size and diversity downstream along a river, but only if the populations are seed-limited. This appears not to be the case for black poplar as Imbert and Lefèvre (2003) found no evidence for genetic structure in downstream direction along the Drome river. Our results therefore imply that areas upstream and also outside or the river bed cannot automatically be considered to be seed-limited or seed-depleted.

\subsection{Comparison among markers}

The overall $F_{\text {st }}$ values were 0.081 for microsatellite data and as much as 0.268 for AFLP data (both highly significant; Table 4, bottom line). The corresponding data of the AMOVA are $7-16 \%$ of the genetic variation present among populations, and the remainder within (all) populations or along (all) rivers. It has been observed that estimates of population differentiation were considerably higher with AFLP than with microsatellite data, in outcrossing trees such as wild apple (Coart et al., 2003) or oaks (Mariette et al., 2002a), in ferns (Woodhead et al., 2005) and also in other organisms such as fish (Garoia et al., 2007). In these cases the population structure as assessed by, e.g., PCO was completely congruent. There are also studies in which quite similar values have been found (see Nybom, 2004 for a discussion). One major reason for the difference in behaviour of the two marker systems (Hedrick, 1999; Mariette et al., 2002b; Nybom, 2004) is the large number of alleles at microsatellite loci. As pointed out by Hedrick (1999), lower among population variation estimates with microsatellite data may be a (mathematical) consequence of the very high levels of 
within-population heterozygosity commonly encountered in microsatellite DNA loci, due to the large number of alleles.

When comparing the $F_{\text {st }}$ values found here for black poplar to related tree species, they turn out to be much higher than what was found for continuous populations of other Populus species. Hall et al. (2007) found $F_{\text {st }}=0.015$ for European aspen (P. tremula) sampled in 12 areas across 10 latitudinal degrees in Sweden. Their study covers an even larger area than ours. In Wisconsin, Cole (2005) found $F_{\text {st }}=0.045$ for $P$. tremuloides, but this was mainly due to one locus (the other loci showed hardly any population differentiation). One cause of the stronger differentiation among our $P$. nigra populations could be the patchiness of its habitat, possibly combined with frequent founder effects. Peng et al. (2005) found $G_{\mathrm{st}}=0.373$ in $P$. cathayana in mountainous areas in China. Hoebee et al. (2006) found already an $F_{\mathrm{st}}=0.067$ in Sorbus torminalis (also a dioecious tree with scattered populations and some clonal propagation) in a region of Switserland with isozymes.

\subsection{Origin of diversity}

The PCO plot of the AFLP data (Fig. 2) is similar to the structure observed for black poplar trees in the genebanks of these countries (Storme et al., 2004). The plot indicates that the positions of the Rhine and Danube samples overlap, while those of the Ebro (Spanish) and Drome (French) samples are plotted quite far apart, and the Ticino (Italian) samples form an intermediate group. Cottrell et al. (2005) interpreted their cpDNA results by assuming that black poplar has had an ice age refugium in Spain, from which France was colonised, and a refugium in the Balkans, from which northwestern Europe was colonised. A refugium in Italy was considered a possibility, as these trees include some unique cpDNA haplotypes. In that case, during postglacial migration the Italian germplasm would have been mixed with that coming from the Balkan (evidenced by haplotype 2 , which occurs in Italy and in eastern and northwestern countries, but not in France). The position of our Italian samples from the Ticino river in the PCO suggests mixing with samples from the Danube river, even though the pairwise genetic distances with Drome and Ebro samples are not larger than those between other populations. This may reflect the much wider gene flow that occurs in the nuclear genome (through seeds plus pollen) compared to the chloroplast genome (through seeds only).

The fact that Ebro and Drome populations are separate in our PCO and Structure analysis seems inconsistent with the latter being colonised from the former. However, while the cpDNA results clearly show that the chloroplast DNA in France come from Spain (Cottrell et al., 2005), this only implies that initially the nuclear diversity in France would have been a subset of the diversity of the populations in Spain that contributed to the colonisation (and a severely bottlenecked subset indeed, as only 6 out of 44 Spanish chloroplast haplotypes are also found in France). The bottleneck may have led to differences in nuclear allele frequencies. In addition, our French sample consists of only one river, with natural dynamics but geographically relatively isolated from the rest of the country. Our Spanish sample consists of one river as well. Although the Ebro did contain many of the cpDNA haplotypes, Cottrell et al. (2005) indicated that the exact refugium is not known and that more structured sampling of Spain would be warranted.

\subsection{Conservation and restoration guidance}

The conservation of genetic resources should preserve the potential for future adaptations of species and populations in the long term, allowing for evolution with special attention to changes in the environment, e.g., climate change/global warming. From this general statement, three operational objectives can be derived for an in situ conservation strategy (Lefèvre et al., 2002):

1. Ensure optimal quantity of regeneration of seeds.

2. Prevent loss of genetic diversity and loss of individuals' fitness.

3. Identify and preserve local or regional gene pools, if existing.

Our results show that there is significant differentiation among populations, even if they occur in one catchment. This is clear for the Danube and, to a lesser extent, for the Rhine. At the same time, it is clear that populations along rivers with insufficient dynamics do not show sufficient natural, sexually derived regeneration. The restoration of the natural habitat and the natural dynamics of the floodplain are the most important measures for the conservation of this species, so that sufficient regeneration can take place in the future. Rood and Mahoney (2000) describe extensive regeneration of cottonwoods after a flood, but indicate that seedlings were absent from areas with insufficient natural populations of mature trees. Hence, to assist natural regeneration whenever needed, several populations should be present, along the length of the catchment. In addition, Guilloy-Froget et al. (2002) advocate more variation in hydrological conditions to enhance seedling establishment along regulated rivers. Hughes et al. (2005) also indicate that for restoration the combination of proper water flow and water table dynamics, sufficient regeneration sites, and sufficient propagation material is necessary.

Population size should be large enough to avoid the effect of drift (random loss of genetic variants due to stochastic processes) on the genetic diversity and on the level of inbreeding. Heterozygosity or allelic diversity has not been lost yet in the populations that we have sampled, which is probably related to the long life span of individual trees. Since poplar is an allogamous species for which an important genetic load is expected, the impact of inbreeding on the mean fitness of the population may be important. For these reasons, restoration of populations should be practised using unrelated clones rather than seed progenies.

\section{Acknowledgements}

This study has been carried out with financial support from the Netherlands' Ministry of Agriculture, Nature and Food Safety, from the Italian Ministry of Environment and 
Environmental Protection (research project 'Application of biotechnology to the protection of the environment, in collaboration with China'), the Ministry of the Environment of the Czech Republic (MZP0002707301), and the Commission of the European Community, Agriculture and Fisheries (FAIR) specific RTD program FAIR-CT97-3386 “Genetic Diversity in River Populations of European Black Poplar for Evaluation of Biodiversity, Conservation Strategies, Nature Development and Genetic Improvement" (EUROPOP). Finalising the analysis and this manuscript was made possible through renewed collaborations and financial support by the European Commission through the Network of Excellence "Evoltree", contract no. 016322, under the 6th Framework Programme, priority 6: sustainable development, global change and ecosystems. It does not necessarily reflect its views and in no way anticipates the Commission's future policy in this area.

\section{Appendix A. Supplementary data}

Supplementary data associated with this article can be found, in the online version, at doi:10.1016/j.foreco.2007. 10.063 .

\section{References}

Arens, P., Coops, H., Jansen, J., Vosman, B., 1998. Molecular genetic analysis of black poplar (Populus nigra L.) along Dutch rivers. Mol. Ecol. 7, 11-18.

Barsoum, N., 2003. Relative contributions of sexual and asexual regeneration strategies in Populus nigra and Salix alba during the first years of establishment on a braided gravel bed river. Evol. Ecol. 15, 255-279.

Barsoum, N., Muller, E., Skot, L., 2004. Variations in levels of clonality among Populus nigra L. stands of different ages. Evol. Ecol. 18, 601-624.

Booy, G., Hendriks, R.J.J., Smulders, M.J.M., Van Groenendael, J.M., Vosman, B., 2000. Genetic diversity and the survival of populations. Plant Biol. 2, 379-395.

Braatne, J.H., Rood, S.B., Heilman, P., 1996. Life history, ecology and conservation of riparian cottonwoods in North America. In: Stettler, R.F., Bradshaw, Jr., H.D., Heilman, P.E., Hinckley, T.M. (Eds.), Biology of Populus and Its Implications for Management and Conservation. NRC Research Press, Canada, pp. 57-86.

Bredemeijer, G.M.M., Cooke, R.J., Ganal, M.W., Peeters, R., Isaac, P., Noordijk, Y., Rendell, S., Jackson, J., Röder, M.S., Wendehake, K., Dijcks, M., Amelaine, M., Wickaert, V., Bertrand, L., Vosman, B., 2002. Construction and testing of a microsatellite database containing more than 500 tomato varieties. Theor. Appl. Genet. 105, 1019-1026.

Cervera, M.-T., Storme, V., Ivens, B., Gusmao, J., Liu, B.H., Hostyn, V., Van Slycken, J., Van Montagu, M., Boerjan, W., 2001. Dense genetic linkage maps of three Populus species ( $P$. deltoids, P. nigra and P. trichocarpa) based on AFLP and microsatellite markers. Genetics 158, 787-809.

Cheliak, W.M., Dancik, B.P., 1982. Genetic diversity of natural populations of a clone-forming tree Populus tremuloides. Can. J. Genet. Cytol. 24, 611-616.

Coart, E., Vekemans, X., Smulders, M.J.M., Wagner, I., Van Huylenbroeck, J., Van Bockstaele, E., Roldán-Ruiz, I., 2003. Genetic variation in the endangered wild apple (Malus sylvestris (L.) Mill.) in Belgium as revealed by AFLP and microsatellite markers. Consequences for conservation. Mol. Ecol. 12, 845-857.

Cole, C.T., 2005. Allelic and population variation of microsatellite loci in aspen (Populus tremuloides). New Phytol. 167, 155-164.

Cottrell, J.E., Forrest, G.I., White, I.M.S., 1997. The use of RAPD analysis to study diversity in British black poplar (Populus nigra L. subsp. betulifolia (Pursh) W. Wettst. (Salicaceae)) in Great Britain. Watsonia 21, 305-312.

Cottrell, J.E., Krystufek, V., Tabbener, H.E., Milner, A.D., Connolly, T., Sing, L., Fluch, S., Burg, K., Lefèvre, F., Achard, P., Bordács, S., Gebhardt, K.,
Vornam, B., Smulders, M.J.M., Vanden Broeck, A.H., Van Slycken, J., Storme, V., Boerjan, W., Castiglione, S., Fossati, T., Alba, N., Agúndez, D., Maestro, C., Notivol, E., Bovenschen, J., Van Dam, B.C., 2005. Postglacial migration of Populus nigra L.: lessons learnt from chloroplast DNA. Forest Ecol. Manage. 206, 71-90.

Dorken, M.E., Eckert, C.G., 2001. Severely reduced sexual reproduction in northern populations of a clonal plant, Decodon verticillatus (Lythraceae). J. Ecol. 89, 339-350.

Douhovnikoff, V., McBride, J.R., Dodd, R.S., 2005. Salix exigua clonal growth and population dynamics in relation to disturbance regime variation. Ecology 86, 446-452.

Excoffier, L., Laval, G., Schneider, S., 2005. Arlequin ver. 3.0: an integrated software package for population genetics data analysis. Evol. Bioinform. 1, 47-50 (Online).

Falush, D., Stephens, M., Pritchard, J.K., 2003. Inference of population structure using multilocus genotype data: linked loci and correlated allele frequencies. Genetics 164, 1567-1587.

Fossati, T., Grassi, F., Sala, F., Castiglione, S., 2003. Molecular analysis of natural populations of Populus nigra L. intermingled with cultivated hybrids. Mol. Ecol. 12, 2033-2043.

Garoia, F., Guarniero, I., Grifoni, D., Marzola, S., Tinti, F., 2007. Comparative analysis of AFLPs and SSRs efficiency in resolving population genetic structure of Mediterranean Solea vulgaris. Mol. Ecol. 16, 1377-1387.

Gaudet, M., Jorge, V., Paolucci, I., Beritognolo, I., Scarascia Mugnozza, G., Sabatti, M., 2008. Genetic linkage maps of Populus nigra L. including AFLPs, SSRs, SNPs, and sex trait. Tree Genet. Genom. 4, 25-36.

Goudet, J., 1995. FSTAT (Version 1.2): a computer program to calculate $F$ statistics. J. Hered. 86, 485-486.

Guilloy-Froget, H., Muller, E., Barsoum, N., Hughes, F.M.R., 2002. Dispersal, germination and survival of Populus nigra (L.) (Salicaceae) in changing hydrologic conditions. Wetlands 22, 478-488.

Hall, D., Luquez, V., Garcia, V.M., St Onge, K.R., Jansson, S., Ingvarsson, P.K., 2007. Adaptive population differentiation in phenology across a latitudinal gradient in European aspen (Populus tremula, L.): a comparison of neutral markers, candidate genes and phenotypic traits. Evolution 61, 2849-2860.

Hedrick, P.W., 1999. Perspective: highly variable loci and their interpretation in evolution and conservation. Evolution 53, 313-318.

Hoebee, S.E., Menn, C., Rotach, P., Finkeldey, R., Holderegger, R., 2006. Spatial genetic structure of Sorbus torminalis: the extent of clonal reproduction in natural stands of a rare tree species with a scattered distribution. Forest Ecol. Manage. 226, 1-8.

Hughes, F.M.R., Rood, S.B., 2003. The allocation of river flows for the restoration of woody riparian and floodplain forest ecosystems: a review of approaches and their applicability in Europe. Environ. Manage. 32, 1233.

Hughes, F.M.R., Colston, A., Owen Mountford, J., 2005. Restoring riparian ecosystems: the challenge of accommodating variability and designing restoration trajectories. Ecol. Soc. 10 (1), 12., http://www.ecologyandsociety.org/vol10/iss1/art12/.

Imbert, E., Lefèvre, F., 2003. Dispersal and gene flow of Populus nigra (Salicaceae) along a dynamic river-system. J. Ecol. 91, 447-456.

Keary, K., A'Hara, S., Whitaker, H., Cottrell, J., 2005. Assessment of genetic variation in black poplar in Ireland using microsatellites. J. Ir. Forestry 62 , $6-18$.

Latouche-Hallé, C., Ramboer, A., Bandou, E., Caron, H., Kremer, A., 2003. Nuclear and chloroplast genetic structure indicate fine-scale spatial dynamics in a neotropical tree population. Heredity 91, 181-190.

Lefèvre, F., Legionnet, A., De Vries, S., Turok, J., 1998. Strategies for the conservation of a pioneer tree species, Populus nigra L., in Europe. Genet. Sel. Evol. 30 (Suppl. 1), S181-S196.

Lefèvre, F., Bordács, S., Cottrell, J., Gebhardt, K., Smulders, M.J.M., Vanden Broeck, A., Vornam, B., Van Dam, B.C., 2002. Recommendations for riparian ecosystem management based on the general frame defined in EUFORGEN and results from EUROPOP. In: Van Dam, B.C., Bordács, S. (Eds.), Genetic Diversity in River Populations of European Black PoplarImplications for Riparian Ecosystem Management. Proceedings of an International Symposium, Szekszárd, Hungary, May 16-20, 2001, pp. $157-161$. 
Legionnet, A., Faivre-Rampant, P., Villar, M., Lefèvre, F., 1997. Sexual and asexual reproduction in natural stands of Populus nigra. Bot. Acta 110, 257-263.

Levine, J.M., Murrell, D.J., 2003. The community-level consequences of seed dispersal patterns. Annu. Rev. Ecol. Evol. Syst. 34, 549-574.

Mahoney, J.M., Rood, S.B., 1998. Streamflow requirements for cottonwood seedling recruitment: an integrative model. Wetlands 18, 634-645.

Mariette, S., Cottrell, J., Csaikl, U.M., Goikoechea, P., König, A., Lowe, A.J., Van Dam, B.C., Barreneche, T., Bodénès, C., Streiff, R., Burg, K., Groppe, K., Munro, R.C., Tabbener, H., Kremer, A., 2002a. Comparison of levels of genetic diversity detected with AFLP and microsatellite markers within and among mixed $Q$. petraea (MATT.) LIEBL. and $Q$. robur L. stands. Silvae Genet. 51, 72-79.

Mariette, S., Le Corre, V., Austerlitz, F., Kremer, A., 2002b. Sampling within the genome for measuring within population diversity: trade-offs between markers. Mol. Ecol. 11, 1145-1156.

Namroud, M.-C., Park, A., Tremblay, F., Bergeron, Y., 2005. Clonal and spatial genetic structures of aspen (Populus tremuloides Michx.). Mol. Ecol. 14, 2969-2980.

Nybom, H., 2004. Comparison of different nuclear DNA markers for estimating intraspecific genetic diversity in plants. Mol. Ecol. 13, 1143-1155.

Peng, Y.P., Lu, Z.X., Chen, K., Luukkanen, O., Korpelainen, H., Li, C.Y., 2005. Population genetic survey of Populus cathayana originating from Southeastern Qinghai-Tibetan Plateau of China based on SSR markers. Silvae Genet. 54, 116-122.

Pospísková, M., Sálková, I., 2006. Population structure and parentage analysis of black poplar along the Morava river. Can. J. Forest. Res. 36, 10671076.

Reisch, C., Schurm, S., Poschlod, P., 2007. Spatial genetic structure and clonal diversity in an alpine population of Salix herbacea (Salicaceae). Ann. Bot. 99, 647-651.

Röder, M.S., Wendehake, K., Korzun, V., Bredemeijer, G., Laborie, D., Bertrand, L., Isaac, P., Rendell, S., Jackson, J., Cooke, R.J., Vosman, B., Ganal, M.W., 2002. Construction and analysis of a microsatellitebased database of European wheat varieties. Theor. Appl. Genet. 106, 67-73.

Rood, S.B., Mahoney, J.M., 2000. Revised instream flow regulation enables cottonwood recruitment along the St. Mary river, Alberta, Canada. Rivers 7, 109-125.
Rood, S.B., Samuelson, G.M., Braatne, J.H., Gourley, C.R., Hughes, F.M.R., Mahoney, J.M., 2005. Managing river flows to restore floodplain forests. Front. Ecol. Environ. 3, 193-201.

Smulders, M.J.M., van der Schoot, J., Geerts, R.H.E.M., Antonisse-de Jong, A.G., Korevaar, H., van der Werf, A., Vosman, B., 2000. Genetic diversity and the reintroduction of meadow species. Plant Biol. 2, 447-454.

Smulders, M.J.M., van der Schoot, J., Arens, P., Vosman, B., 2001. Trinucleotide repeat microsatellite markers for black poplar (Populus nigra L.). Mol. Ecol. Notes 1, 188-190.

Storme, V., Vanden Broeck, A., Ivens, B., Halfmaerten, D., Van Slycken, J., Castiglione, S., Grassi, F., Fossati, T., Cottrell, J.E., Tabbener, H.E., Lefèvre, F., Saintagne, C., Fluch, S., Krystufek, V., Burg, K., Bordács, S., Gebhardt, K., Vornam, B., Pohl, A., Alba, N., Agúndez, D., Bovenschen, J., Van Dam, B.C., Van der Schoot, J., Vosman, B., Boerjan, W., Smulders, M.J.M., 2004. Ex-situ conservation of black poplar in Europe: genetic diversity in nine gene bank collections and their value for nature development. Theor. Appl. Genet. 108, 969-981.

Van der Schoot, J., Pospíšková, M., Vosman, B., Smulders, M.J.M., 2000. Development and characterization of microsatellite markers in black poplar (Populus nigra L.). Theor. Appl. Genet. 101, 317-322.

Van Splunder, I., Coops, H., Voesenek, L.A.C.J., Blom, C.W.P.M., 1995. Establishment of alluvial forest species in floodplains: the role of dispersal timing, germination characteristics and water level fluctuations. Acta Bot. Neerl. 44, 269-278.

Vekemans, X., Beauwens, T., Lemaire, M., Roldan-Ruiz, I., 2002. Data from amplified fragment length polymorphism (AFLP) markers show indication of size homoplasy and of a relationship between degree of homoplasy and fragment size. Mol. Ecol. 11, 139-151.

Vos, P., Hogers, R., Bleeker, M., Reijans, M., Van de Lee, T., Hornes, M., Frijters, A., Pot, J., Peleman, J., Kuiper, M., Zabeau, M., 1995. AFLP: a new technique for DNA fingerprinting. Nucleic Acids Res. 23, 4407-4414.

Winfield, M.O., Arnold, G.M., Cooper, F., Le Ray, M., White, J., Karp, A., Edwards, K.J., 1998. A study of genetic diversity in Populus nigra subsp. betulifolia in the upper severn area of the UK using AFLP markers. Mol. Ecol. 7, 3-10.

Woodhead, M., Russell, J., Squirrel, J., Hollingsworth, P.M., MacKenzie, K., Gibby, M., Powell, W., 2005. Comparative analysis of population genetic structure in Athyrium distentifolium (Pteridophyta) using AFLPs and SSRs from anonymous and transcribed gene regions. Mol. Ecol. 14, 1681-1695. 